\title{
En særlig kvindelig skaberkraft
}

Eva Pohl: Et lyst værelse. Empati, rumopfattelse, kunstnerisk selvspejling og æstetik $i$ kvindelige danske forfatteres og billedkunstneres værker i perioden 1930-90. Syddansk Universitetsforlag 2016, 129 sider.

Findes der en særlig kvindelige æstetik, en særlig tilgang til og tematisering af kunstnerisk skabelse? Eva Pohls tese er, at det gør der. Hun mener, at "empati er et grundlæggende element i kvindelige forfatteres og billedkunstneres værker"; at "Kvinder og mænd træder ind $\mathrm{i}$ et rum på forskellige måder" (s. 10), og at kvinders måde at være i rummet og verden på viser sig i deres billeder og tekster, i deres formsprog og deres motiver. Oplevelsen af rummet er konstituerende for både kvinders og mænds væren i verden, men Pohl siger at kvinders er kendetegnet ved på den ene side det oceaniske, strømmende, på den anden side en spaltning, der kan henføres til kvinders (potentielle) moderskab. Under graviditeten oplever kvinder, siger hun med Julia Kristeva, at have to adskilte rum i sig. I Kristevas optik vanskeliggør denne spaltning kvinders adgang til kunstnerisk skabelse, mens Pohl især er optaget af, hvordan de to erfaringsmåder kommer til udtryk hos kvindelige forfattere og billedkunstnere i perioden 1930-90 som tematiseringer af rummet og lyset, bevægelsen mellem det lukkede og det universelle og som overvejelser over kreativiteten og dens betydning.

Det indledende kapitel præsenterer den generelle rum-teori hos George Bachelard og Maurice Melau-Ponty og de franske teoretikere Julia Kristeva og Hélène Cixous' overvejelser over forbindelsen mellem kvinders kropsoplevelse og den kunstneriske skabelse. Hvor Kristeva bemærker spaltningen, fordoblingen af kroppens rum, understreger Cixous den strømmende, vilde, oceaniske og generøse kraft, hun oplever, når hun skriver. Pohl peger på Susanne Ussings skulptur I drivhuset (1980), hvor en gigantisk kvindekrop er spærret inde i et drivhus, som hun ville sprænge, hvis hun rejste sig. Sådan, siger Pohl, kan man hos kvinderne finde en bestræbelse, en længsel mod at sprænge rammerne, en kunst, der søger væksten og lyset og dynamiserer rummet. Rummet er det fænomenologiske rum, det kvindelige kropsrum, men også det helt konkrete rum, som kvinderne kræver for at kunne skabe, ikke for at lukke sig inde i det, men for, siger hun med Suzanne Brøgger, at kunne sprænge rummets grænser. Kreativiteten er også selvskabelse, et behov og en stor glæde for mange af de kvinder, hun inddrager i sine analyser. Bogens centrale tese er da, at kvindelige kunstnere skaber på en særlig måde, og dens politiske hensigt er at gøre opmærksom på både deres særpræg og deres kvaliteter, fordi "det kvindelige blik er en afgørende ressource for kunsten" (s. 25). 
Det er dette blik, hun følger i de næste fem kapitler, der kronologisk behandler en række forfattere og billedkunstnere og søger lighedstræk hos dem. Kapitlerne tager alle afsæt i en forfatter (Karen Blixen, Tove Ditlevsen, Inger Christensen, Dorrit Willumsen og Pia Tafdrup), og karakteriserer et udvalg af deres værker, hvorefter Pohl bevæger sig mod samtidige malere. Hun læser og ser efter de særligt kvindelige æstetiske træk hos forfattere og malere og deres mulige korrespondance med hinanden. Vægten ligger således mere på motiviske ligheder end på den historiske udvikling, selvom hun i forbindelse med læsningen af Dorrit Willumsens roman Marie (1983) bemærker, at man her ser tidens optagethed af kvindelig selvrealisering i beskrivelsen af Marie Tussauds stærke engagement i sit skabende arbejde med voksmodeller.

I Karen Blixens tekster undersøger hun "temaerne identitet, sanselighed, receptivitet, rumopfattelse, oceanisk følelse og kunstnerisk selvspejling" (s. 33). Udgangspunktet er den ufuldendte historie "Kyriatiderne" (1957), hvor den unge kvinde Childeriques erotiske længsler kontrasteres af de uforanderlige tempelbærende kyriatidefigurer. Den unge kvinde vil andet og mere, og hendes sanselighed forbindes med naturen og det strømmende vand. Denne læsning bringer Pohl til et maleri af Ebba Carstensen, Skov med liggende pige (1943), der også er valgt som forsidebillede til bogen. Her finder hun en afbildningen af en kvinde, der vælger at ligge i skoven, der er domineret af lysende farver og det Pohl kalder en både drømmende og dynamisk atmosfære. På samme vis fører en scene mellem Childerique og hendes barn til Tove Olafssons bronzeskulptur Mor ammer sit barn. Siddende nøgen kvinde (1956). Det er Pohls omfattende indsigt i periodens kvindelige malere og skulptører, der danner grundlag for sammenføringerne. Samtidig med, at de insisterer på et fællesskab i opfattelsen af liv, krop og kunst, rejser de også et spørgsmål for læseren om grundlaget for valget af kunstnere og deres værker. Er de repræsentative? Skal de være det? Er bogen snarest et langt argument for, disse temaer findes hos forfatter efter forfatter, billedkunstner efter billedkunstner?

De kvindelige kunstnere er ikke blot optaget af krop, natur og sanselighed, men også af transcendens, siger hun og jævnfører Karen Blixens optagethed af månen med Elsa Alfelts udsagn om, at hun er "måneskudt". Bevægelsen mod transcendens finder Pohl også i Alfelts naturbilleder, hvor sol og måne, siger hun, repræsenterer kvinder, mens bjergene står for det mandlige. Bevægelsen mod kosmos er central i Inger Christensens digtning, hvor tematiseringen af lys, sprog, kosmos og skabelse får Pohl til at sammenligne hendes tekster med med Elsa Alfelts lysmættede billeder, hvis penselstrøg karakteriseres som oceaniske.

Den kvindelige kreativitet er et andet centralt motiv i Et lyst værelse; det findes i Blixens tekster om sangeren Pellegrina, i Tove Ditlevsens kunstneriske drift (der også, siger Pohl, rummer angst og sårbarhed), der minder om Franziska Clausens kunstneriske metode og dens brud med den abstrakte stringens, som hun var indlært i. Den findes igen i Inger Christensens tekster om erkendelse og nydelse i den kunstneriske proces, i Dorrit Willumsens roman om den kvindelige kunstner, i Pia Tafdrups tematisering af lysten og energien i det at skrive det endnu ikke eksisterende frem. Og tilsvarende hos en række billedkunstnere, f.eks. Anna Klindt Sørensens og Olivia Holm Møllers selvportrætter og hos senere billedkunstnere som Kir- 
sten Justesen og Jytte Rex. Tematiseringen af den kunstneriske proces er central for bogens ærinde: den peger mod den særlige kvindelige oplevelse af kroppen og rummet, den peger mod den kvindelige forbindelse med det energisk strømmende og oceaniske (men også mod angsten som motiv), og den peger mod transcendensen som motiv og perspektiv hos kunstnerne. Den særligt kvindelige tilgang til kunsten er for Pohl både forbundet til et kvindeligt erfaringsrum og til hele kosmos. Det er ikke blot narcissisme, der får kvinderne til at være optaget af selvfremstilling (som hos Cindy Sherman), af spejlet, af deres egen krop under f.eks. graviditet (Kirsten Justesen er her eksemplet), men også altid en bevægelse mod transcendens og universalitet. Heri kan læses et argument for et både anderledes og stærkere fokus på kvindelige kunstnere.

Et lyst værelse præsenterer i sig selv et anderledes blik på kvinders litteratur- og billedkunsthistorie, og den tværæstetiske tilgang er givende og føjer nyt til ikke mindst kunsthistorien. Værket er funderet i en bred teoretisk læsning og omfattende indsigt i kvinders litteratur og især malerkunst i perioden, tilgangen er på samme tid associerende og tilnærmelsesvis generaliserende, fordi postulatet er, at den empatiske optagethed af det erotiske og oceaniske, både som noget der er funderet i kvinders kroppe og erfaringer og som en bestræbelse, der omfatter og transcenderer den kunstneriske skabelse, er et fællestræk ved kvinders tilgang til litteratur og kunst. Det handler på én gang om motiver, om refleksion over kreativiteten, om en særlig tilgang til verden og om specifikke kunstneriske former. Der er selvfølgelig tale om en tilskæring af 60 års litteratur og billedkunst, men også om et manifest, der genopliver en tænkning i Écriture et peinture féminine, som øvede en stærk og inspirerende indflydelse på kønsteorien i 1980'erne, men siden er fortrængt af den performative og dekonstruktive tilgang til kønnene. Derfor kan Pohls Et lyst værelse vække en vis undren, men omvendt også en nysgerrighed over for de motiver hos kvindelige forfatter og kunstnere, hun uden at ryste på hånden fremhæver som karakteristiske og kvindelige. Der kan måske også anes forbindelseslinjer til den nye materialisme, der ganske vist ikke undsiger diskurser og dekonstruktion, men vægter kropserfaringen.

Men bogen kan også være svær at følge; Eva Pohl mimer i sin stil det associerende og glidende, som hun undersøger hos udvalget af forfattere og billedkunstnere, fundamentet er videnskabeligt med grundige henvisninger og brug af teori og andre analyser af især forfatterskaberne, mens formen undviger argumenter for inddragelse af denne eller hin kunstner og insisterer på at finde ligheder, der tilsammen etablerer en form for fællesskab mellem de behandlede kunstnere. Fællesskabet er ikke baseret på intertekstuelle henvisninger, en gensidig inspiration; det er suverænt funderet på Pohls viden og valg, og de sidste er bogen ganske tavs om. "Abrikoserne findes", skriver Inger Christensen i Alfabet (1981), det er den samme sproglige (performative) skabelsesakt, man finder i Eva Pohls tilgang, hvor det implicitte argument synes at være, at teksterne, billederne, forfatterne, billedkunstnerne og temaerne findes; derfor har de den status, hun insisterer på. Metoden kan kaldes eksemplifikation kombineret med association.

Man tvivler ikke på Pohls viden, men læseren snubler over den manglende argumentation bag associationskæderne. De forbliver private. Bogen åbner nok blik- 
ket for linjer og forbindelser mellem forfattere og kunstnere og kunne blive til en interessant udstilling (det er kun en del af billedmaterialet, der er gengivet), men efterlader også læseren med stor usikkerhed. Hvor signifikante er motiverne i de kvindelige kunstneres samlede produktion i perioden? Er bevægelsen fra krop og sprog mod kosmos kun til stede hos kvindelige kunstnere? Hvad med de historiske linjer? Og hvor vil Eva Pohl selv placere sin tilgang i forhold til de sidste snart 50 års kvinde- og kønsteorier? Bogen insisterer stædigt-suverænt på et særligt kvindeligt erfaringsrum og en særlig kvindelig tilgang til kunsten, der er langt fra dagens blanding af performativitetsteori og mulig ny feministisk materialisme, men man savner konturerne af en dialog med andre tilgange til stoffet. Der er interessante iagttagelser af f.eks. Franziska Clausens brud med de rette linjer, som Piet Mondrian bedrev dem, og her mærker man afsættet til en analyse af kvindelige kunstneres samspil med samtidens ismer, en kontekstualisering af deres valg og særpræg, som ellers generelt er fraværende.

Bogens berettigelse er dens øjenåbnende beskrivelse af motiver i kvinders kunst, der forklarer deres blik på liv, kunst og verden som et perspektiv, der strækker sig og forbinder kroppen og universet. Dens begrænsning er den flimrende, associerende tilgang, der gør det vanskeligt for læseren at hitte rede i selektioner og forbindelseslinjer. Et lyst værelse efterlader mange spørgsmål, og et væsentligt er, om den for alvor bliver det politiske argument, som den gerne vil være for et nyt syn på og en ny vurdering af kvindelige kunstnere, der kunne revidere deres placering i kunsthistorien.

Anmeldt af Anne Birgitte Richard

\section{Nyere dansk litteraturhistorie til udlandet}

Anne-Marie Mai: Danish literature in the 20th and early 21st century. Odense: Syddansk Universitetsforlag 2017, 278 sider.

Forsiden på Anne-Marie Mais engelsksprogede præsentation af dansk litteratur i den 20. århundrede og lidt til prydes af en håndfuld børn, der kravler rundt på H.C. Andersen-statuen i Central Park i New York. Et stykke dansk litteratur midt ude i den store verden og vel sagtens indbegrebet af denne litteratur. Man kan betragte bogen som et forsøg på at udvide denne opfattelse fremefter. Den er så at sige et opgør med sin egen forside. Og et meget kompetent opgør, kan jeg lige så godt røbe med det samme.

Bogen er, som Anne-Marie Mai selv nævner i indledningen, skrevet på baggrund af hendes store arbejde med det 20. århundredes danske litteratur, især redaktionen af Danske digtere i det 20. århundrede I-III, hvor man finder fyldige efterskrifter til hver bind, og hendes danske litteraturhistorie, Litteraturen finder sted I-III. Man kunne tilføje hendes nyeste udspil Galleri 66. En historie om nyere dansk litteratur. Især de to sidste eksperimenterer med at skrive anderledes litteraturhistorie, det 